\title{
NOVEL AND QUICK SENSOR RESPECTIVE FOR SULFATE
}

WAGIHA H. MAHMOUD*, MOHAMED M. ABO ALY, MOHAMED S.. HAMZA, SABAH M. MOLTAZEM

Department of Chemistry, faculty of science, Ain Shams University, Cairo, Egypt.

\begin{abstract}
A sulfate-selective PVC-membrane sensor based on nickel complex of 3, 8-dimethyl 5, 6benzo- 4, 7-diazadece-3, 7-diene-2, 9-dione (dioxime) as (a novel sensing material) is presented. The Potentiometric behavior of the sensor was independent on the $\mathrm{pH}$ of the solution between 4.5 and $7.5 \mathrm{pH}$. The sensor revealed a linear response towards $\mathrm{SO}_{4}{ }^{2-}$ ion in the range of $5.0 \times 10^{-7}$ to $1.0 \times 10^{-2} \mathrm{M}$ with an anionic slope of $-30 \pm 0.2 \mathrm{mV}$ per decade. The sensor possesses a satisfactory reproducibility, fast response time, low limit of detection $\left(3 \times 10^{-7} \mathrm{M}\right)$. The interference of hydrophobic inorganic anions was very low in comparison with the conventional ion-exchanger based electrodes, as shown by the selectivity coefficients determined by the separate solution method (SSM). The selectivity was also good towards the most common univalent and divalent anions. The sensor was used as an indicator electrode in potentiometric titration of sulfate with barium ions and in determination of sulfate in some pharmaceutical products .
\end{abstract}

Keywords: Sulfate ion-selective sensor ; 3, 8-dimethyl 5, 6-benzo- 4, 7-diazadece-3, 7-diene-2, 9-dione (dioxime); PVC-membrane; Potentiometry

\section{Introduction}

The quick determination of minute quantities of ionic species by simple methods in a wide variety of real samples, as well as the growing interest in the host guest chemistry of anions [1] thus a new areas of application have opened up as a result of these improved characteristics and they are of great importance in analytical chemistry. Potentiometric detection based on ion selective electrodes (ISEs) is the simplest of all other analytical techniques and offers great advantages such as speed and ease of preparation and procedures, wide dynamic range often spanning about five decades of ion concentration, and low cost, no sample destruction and short response time. These characteristics have inevitably led to sensors for several ionic species,(2-4) and the list of available sensors has grown substantially over the past decades. Among different anions, the recognition of strongly hydrophilic anions such as $\mathrm{SO}_{4}{ }^{2-}$ by potentiometric methods has shown to be quite difficult [1-4]. Thus, despite the urgent need for selective potentiometric determination of minute amounts sulfate ion in many chemicals, pharmaceutical, environmental and 
industrial samples, only a few reports on the preparation of $\mathrm{SO}_{4}{ }^{2-}$ ion-selective electrodes are available in the literature [5-9]. None of the solid state sulfate ionselective electrodes has reported to be satisfactory, due to the lack of adequate selectivities [4].Recently, new sulfate ion-selective electrodes based on a bisthiourea ionophore []], a derivative of imidazole [7] and a zwitterionic bisguanidinium ionophore as a sulfate carrier [ 8 ] have been reported. Although, these electrodes show a close Nernstian behavior over a relatively wide concentration range, they suffer from rather strong interferences from such other anions as $\mathrm{NO}_{2}{ }^{-}$, $\mathrm{NO}_{3}{ }^{-}, \mathrm{Br}^{-}, \mathrm{I}^{-}, \mathrm{ClO}_{4}^{-}$and $\mathrm{SCN}^{-}$[6- $\left.\underline{8}\right]$.

In ISEs, selectivity is introduced by the receptor molecules (or ionic carrier) which are generally immobilized in a polymeric membrane matrix, often consisting of high molecular weight poly(vinyl chloride) (PVC) mixed with a plasticizer. The receptor molecule attributes selectivity to the sensor by its strong and selective interactions with the target analyte.

Due to vital importance of sulfate determination in chemical, pharmaceutical, environmental and industrial analyses, we were interested in preparation of a new PVC-based membrane sensor for sulfate ion monitoring in solution. In this paper, we report a highly selective PVC-membrane sulfate ion-selective electrode based on nickel complex of 3, 8-dimethyl 5, 6-benzo- 4, 7-diazadece-3, 7-diene-2, 9-dione (dioxime) as an excellent ionic carrier .

\section{Experimental}

\section{Reagents and materials}

All chemicals were of analytical reagent grade. Dioctyl phthalate (DOP), dioctyl sebacate (DOS), tetrahydrofuran (THF), and high relative molecular weight PVC were purchased from Aldrich chemical company and used as received. Potassium salts of all anions used (all from Merck) were of the highest purity available and used without any further purification except for vacuum drying over $\mathrm{P}_{2} \mathrm{O}_{5}$. Doubly distilled deionized water was used throughout. The chelating agent $\mathrm{H}_{2} \mathrm{~L}$ was synthesized and purified as described elsewhere [10]. The chloro-nickel complex of this ligand $[\mathrm{Ni}(\mathrm{HL})] \mathrm{Cl}$ was prepared by the direct reaction of equal quantities of the ligand ( solvent used 50\% ethyl alcohol and 50\% water) and $\mathrm{NiCl}_{2}$ solution (used water as a solvent) of concentration $1 \times 10^{-2} \mathrm{M}$. The red precipitate was filtered, washed with water, dried at room temperature and incorporated as electro- active material in the formation of the selective membrane respective for sulfate ions. 


\section{Electrode preparation}

The general procedure to prepare the PVC membrane was to mix thoroughly $190 \mathrm{mg}$ of powdered PVC, $350 \mathrm{mg}$ of plasticizer DOP or DOS, and $10 \mathrm{mg}$ of the elctroactive $[\mathrm{Ni}(\mathrm{HL})] \mathrm{Cl}$. Then, the mixture was dissolved in $5 \mathrm{ml}$ of THF. The resulting clear mixture was evaporated slowly at room temperature for 24 hour until an oily concentrated mixture was obtained. The membrane was sectioned with cork porer $(10 \mathrm{~mm}$ diameter) a disk $(0.1 \mathrm{~mm})$ thick was cut from the transparent membrane and glued to PVC tube (using THF) as previously described [11]. The tube was then filled with the internal solution $\left(1.0 \times 10^{-3} \mathrm{M} \mathrm{K}_{2} \mathrm{SO}_{4}\right)$. The electrode was finally conditioned for $24 \mathrm{~h}$ by soaking in a $1.0 \times 10^{-3} \mathrm{M}$ potassium sulfate solution until a stable potential value was obtained, according to a widely accepted practice. A silver-silver chloride electrode was used as an internal reference electrode

\section{The emf measurements}

All emf measurements were carried out with the following assembly: $\mathrm{Ag}-\mathrm{AgCl}|\mathrm{KCl}(3 \mathrm{M})|$ internal solution, $1.0 \times 10^{-3} \mathrm{M} \mathrm{K}_{2} \mathrm{SO}_{4} \mid \mathrm{PVC}$ membrane $\mid$ test solution $\mathrm{Ag}-\mathrm{AgCl}$

All potentiometric measurements were made at $25 \pm 1^{\circ} \mathrm{C}$ with an Orion digital $\mathrm{pH}$ /mV using PVC- nickel - 3, 8-dimethyl-1, 5, 6-benzo- 4, 7-diazadece-3, 7-diene-2, 9-diome (dioxim) sulfate membrane sensor in conjunction with an Orion double junction $\mathrm{Ag} / \mathrm{AgCl}$ reference electrode ( Model 90-02) filled with $10 \% \mathrm{w} / \mathrm{v} \mathrm{KNO}_{3}$ in the outer compartment. An Orion combination pH electrode (model 91-02) was used for all $\mathrm{pH}$ adjustment.

\section{Results and Discussion}

The wide uses of ISEs in routine chemical analysis have been accompanied by a search for ionophores that can chemically recognize specific ions and offer either new or improved selectivities for different ions. In the literature, the membranes used in anion selective sensors are based on quaternary ammonium or phosphonium salts [5-8]. In the case of most anion-selective electrodes, there are relatively few examples of the use of ionophores. These include the derivatives of bis-thiourea []], imidazole [7], cytosine [13] and guanidinium ion [4, 14], as well as different and macrocyclic polyamines [15-18]. Due to low lipophilicily of sulfate ion, the design of a selective ligand for its selective recognition has been a challenging subject [6-8 , 18-20]. Some neutral carriers such as bis-thiourea [12] and imidazole [7] derivatives 
possessing high enough lipophilicity and specific host-guest interactions with sulfate ion have recently shown to be promising for this purpose.

Identification of the new synthesized Ni-dioxime complex

The structure of the prepared red Ni-dioxime sulfate complex was confirmed Via elemental analysis and electronic spectra. The results obtained was compared with that of the chelating agent under the same conditions. The data of the elemental analysis was tabulated in table 2 . this data confirmed the formation of $[\mathrm{Ni}(\mathrm{HL})] \mathrm{Cl}$ complex. The U.V spectra of that complex is similar to that previously reported for Ni-dimethylglycozimate [22], these results was confirmed by I.R spectra. The $v$ $\mathrm{C}=\mathrm{N}$ appear at 1629 in the I.R spectra of the ligand was shifted to $1649 \mathrm{Cm}^{-1}$ in the complex spectra. A new band at $519 \mathrm{Cm}^{-1}$ respective for $\mathrm{Ni}-\mathrm{N}$ was observed also there are two new bands at 1240 and $1100 \mathrm{Cm}^{-1}$ respective for cyclic skeleton of the complex. The I.R spectra of the prepared membrane was evaluated before and after socking in $10^{-3} \mathrm{M} \mathrm{K}_{2} \mathrm{SO}_{4}$ solution. The prepared complex was preformed using $\mathrm{NiSO}_{4}$ and the resulted ppt was measured by I.R the spectra give a new band at about $1050 \mathrm{Cm}^{-1}$ indicating the presence sulfate group in the prepared complex.

\section{Characterization of the membrane sensor}

Among different membrane compositions tested, membrane with proportion $1 \%$ [Ni(HL)]Cl ionic carrier,33\% PVC, 66\% plasticizer DOP or DOS, offers the best sensitivity as well as the widest linear range, with a Nernstian slope of about $-30 \mathrm{mV}$ per decade (Table1). From the (fig 2), it is immediately obvious that the nature and amount of additive did not influence the performance characteristics of the membrane sensor significantly. It can be seen that the two sensors prepared, showed a linear Potentiometric response over a wide concentration range of $5 \times 10^{-7}-1 \times 10^{-2}$ $\mathrm{M}$ sulfate ions concentration with a slope of $-30.04 \mathrm{mV}$ per decade of sulfate ions and a correlation coefficient of 0.9998 . The slopes of the calibration graphs is Nernstian compared with the sub-Nernstian or over-Nernstian slopes given by some other sensors [23-25]. The linear range of the sensor response for $\mathrm{SO}_{4}{ }^{2-}$ is about five decades of concentration, which is 1-2 decades greater than those reported for some other sulfate ions electrodes. The limits of detection, defined as the concentration of sulfate ions obtained when extrapolating the linear calibration region to the baseline potential, are given in (fig 2). As can be seen, the sensor showed detection limits of $(0.288 \mathrm{ppm})$, which are better than those of most other sulfate sensor. The limits of detection obtained in this work are several orders of magnitude below the sulfate concentration in pharmaceutical samples[15-24,19-21]. 
The influence of the concentration of internal solution on the potential response of the $\mathrm{SO}_{4}{ }^{2-}$ ion-selective sensor was studied. The $\mathrm{K}_{2} \mathrm{SO}_{4}$ concentration was changed from $1.0 \times 10^{-7}$ to $1.0 \times 10^{-2} \mathrm{M}$ and the emf were recorded. It is seen that the variation of the concentration of the internal potassium sulfate solution does not cause any significant difference in the potential response, except for an expected change in the intercept of the resulting Nernstian plots. A $1.0 \times 10^{-3} \mathrm{M}$ concentration of the reference solution is quite appropriate for smooth functioning of the sensor system.

The $\mathrm{pH}$ sensitivity of the proposed electrode was examined by obtaining the potential responses of the membrane electrode in $1.0 \times 10^{-3}$ and $1.0 \times 10^{-4} \mathrm{M}$ sulfate solution at $\mathrm{pH} 2-9$, and the results are shown in Fig. 3. As seen, the most sensitive potential response is obtained at a $\mathrm{pH} 4$ - 7.5. At $\mathrm{pH}$ values lower than 4 , the sensor seems to respond to proton significantly while at higher $\mathrm{pH}$ values, the ionic carrier has presumably a low tendency for sulfate ions.

The response time of the proposed sulfate sensor for step changes in concentration of $\mathrm{SO}_{4}{ }^{2-}$ ion, from low to high concentrations are shown in Fig. 4. As seen, the time for the electrode to reach $90 \%$ of the steady response was $<15 \mathrm{sec}$ and no change is normally observed up to $5 \mathrm{~min}$. Potentional were monitored periodically at fixed concentration and standard deviation of ten identical measurements was 2.0 $\mathrm{mV}$. In term of the life of the PVC membrane sensor, the response stability was observed for over more than 6 months.

The potentiometric selectivity coefficients, describing the preference by the PVC membrane incorporating the ionic carrier for an interfering ion, B, relative to sulfate ion, A, were determined by the separate solution method (SSM), which is recommended by IUPAC [26]. In these method, the selectivity coefficients of sulfate sensor was evaluated graphically at fixed concentration of sulfate ion and interferant as shown in (fig. 5) As it is seen, excellent selectivity coefficients in the order of $10^{-3}$ and lower are obtained for a large number of inorganic and organic anions indicating insignificant interfering effect of these anions on the sulfate ion determination, by the proposed membrane sensor are given in( Table 3 ).

A typical selectivity patteran for a series anions showed by the electrode is as follows $\mathrm{SO}_{4}{ }^{2-}>\mathrm{SO}_{3}{ }^{2-}>\mathrm{CO}_{3}{ }^{2-}>\mathrm{S}_{2} \mathrm{O}_{3}{ }^{2-}>\mathrm{HPO}_{4}{ }^{2-}>\mathrm{B}_{4} \mathrm{O}_{7}{ }^{2-}>\mathrm{CH}_{3} \mathrm{COO}^{-}>\mathrm{BrO}_{3}{ }^{-}>\mathrm{Cl}^{-}$ $>\mathrm{IO}_{4}^{-}>\mathrm{NO}_{3}^{-}>\mathrm{HCO}_{3}^{-}>\mathrm{SCN}^{-}>\mathrm{NO}_{2}^{-}>\mathrm{ClO}_{4}^{-}$. 
So the electrode is highly selective towards sulfate over several organic and inorganic anions. In Table 4, the selectivity coefficients of proposed sensor was compared with those reported before (27-35). Noteworthy, this is just a gross relative comparison, since the selectivity data have been reported using different experimental method, as indicated in Table 4 it is clearly indicated that a tremendous enhancement in selectivity behavior of the proposed sensors for $\mathrm{SO}_{4}{ }^{2-}$ ions.

\section{Analytical Application}

The proposed membrane sensor was found to work well under laboratory conditions. It is successfully used as an indicator electrode in titration of a sulfate ion solution $\left(1.0 \times 10^{-2}, 1.0 \times 10^{-3}, 5.0 \times 10^{-3} \mathrm{M}\right)$ with $\mathrm{Ba}^{2+}$ ion $\left(1.0 \times 10^{-2} \mathrm{M}\right)$ and vice versa. The results of both the titrations are shown in (Fig. 6) indicating that the amount of $\mathrm{SO}_{4}{ }^{2-}$ or $\mathrm{Ba}^{2+}$ ions can be accurately determined with the proposed sensor.

The sensor was also applied to the determination of sulfate concentration in some pharmaceutical products using direct potentiometry, as example .Neomycine tablets, Visceralgin tablets, also streptomycin powder injection, the sulfate was determined in this three drugs using the proposed sensor, the results are favorably compared by turbidemetry method as standard method (Table 5)

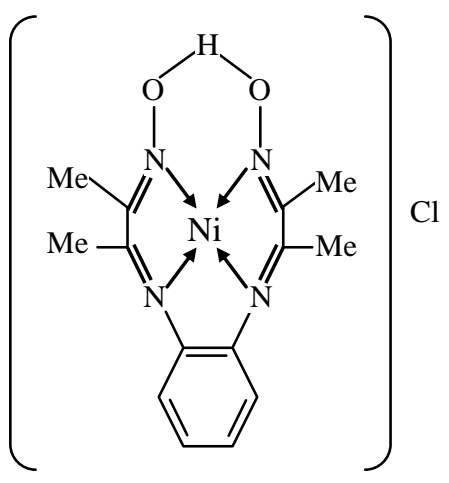

Fig. (1) Structure of Ni dioxime (complex)

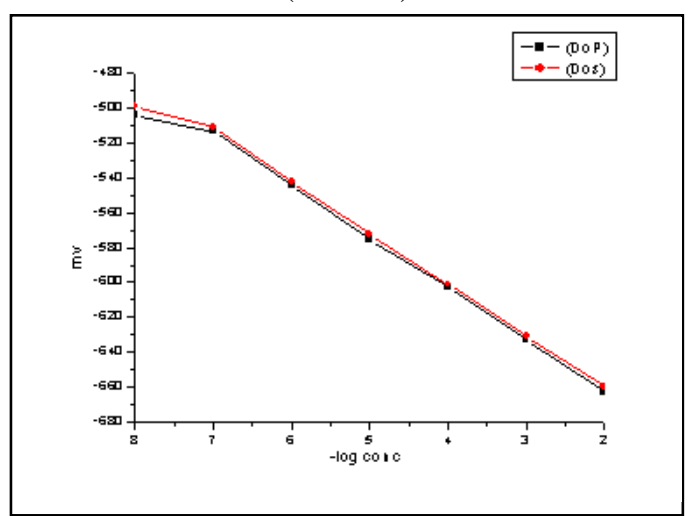

Fig. (2) Potentimetric response curves for the sensor at different plasticizers

Table (1) Response characteristics of the $\mathrm{Ni}$ - dioxime -PVC sulfate membrane sensor

\begin{tabular}{|l|c|}
\hline Slope, $\boldsymbol{m}$ V/decade & -30.3 \\
\hline Liner concentration range, $(\mathrm{M})$ & $5 \times 10^{-7}$ to $10^{-2}$ \\
\hline Lower limit of detection , (M) & $3 \times 10^{-7}$ \\
\hline Response time, $(\mathrm{s})$ & $<15$ \\
\hline Working range $(\mathrm{pH})$ & $4.5-7.5$ \\
\hline Intercept, $\mathrm{mV}$ & 710 \\
\hline Correlation Coefficient , (r) & 0.999 \\
\hline
\end{tabular}




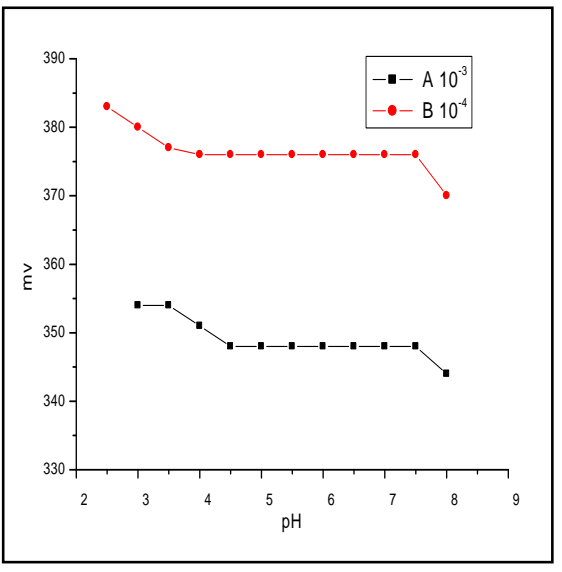

Fig. (3) Effect of $\mathrm{pH}$ on the potential response of the proposed sulfate sensor selective electrode .

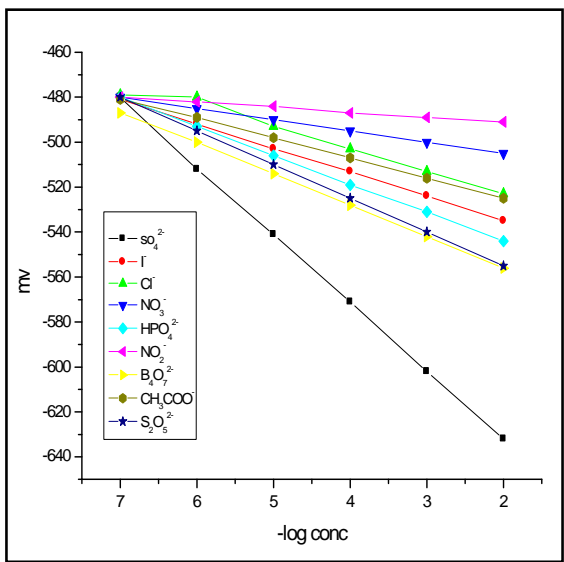

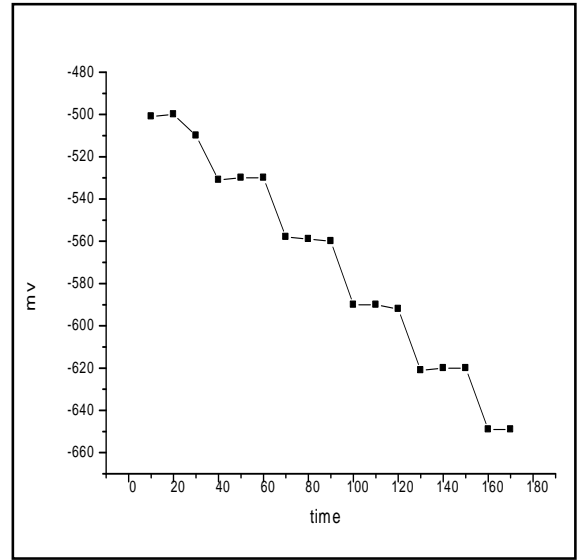

Fig. (4) Dynamic response time of Nidimethyl benzo diazadece diene dione membrane electrode for step changes concentration of sulfate from $1 \times 10^{-7}-10^{-2} \mathrm{M}$.

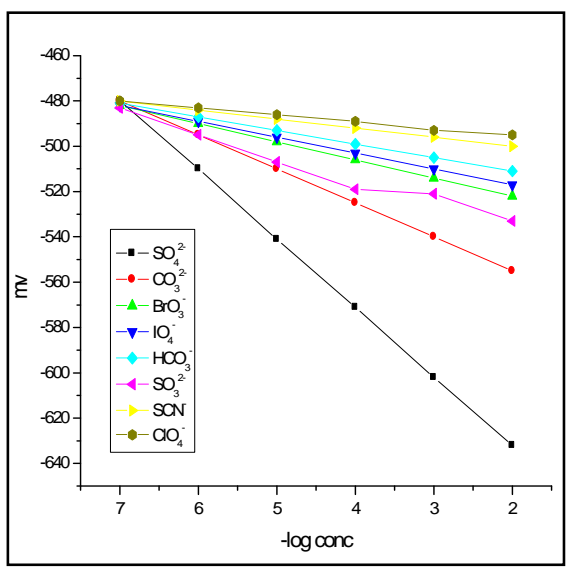

Fig. (5). Potential response of sulfate PVC membrane sensor based on $\mathrm{Ni}$ - dioxime for various ions . 
Table (2) Elemental analysis of Ni- dioxime complex .

\begin{tabular}{|c|c|c|c|c|}
\hline Sample & & $\mathrm{C} \%$ & $\mathrm{H} \%$ & $\mathrm{~N} \%$ \\
\hline Ni-complex & Calculated & 44.7 & 4.81 & 15.9 \\
\hline Ni-complex & Found & 43.8 & 4.64 & 17.29 \\
\hline
\end{tabular}

Table.(3) Selectivity coefficients for Ni-dioxime PVC- sulphate membarane sensor.

\begin{tabular}{|c|c|}
\hline Interferent, $\boldsymbol{I}$ & $\mathrm{K}^{2-}{ }^{2-}$ \\
\hline $\mathrm{IO}^{-}$ & $2.71 \times 10^{-3}$ \\
$\mathrm{Cl}^{-}$ & $8.57 \times 10^{-4}$ \\
$\mathrm{IO}_{4}{ }^{-}$ & $7.35 \times 10^{-4}$ \\
$\mathrm{ClO}_{4}{ }^{-}$ & $1.99 \times 10^{-4}$ \\
$\mathrm{BrO}_{3}{ }^{-}$ & $1.07 \times 10^{-3}$ \\
$\mathrm{~B}_{4} \mathrm{O}_{7}^{-}$ & $2.15 \times 10^{-3}$ \\
$\mathrm{SO}_{3}{ }^{2-}$ & $8.51 \times 10^{-3}$ \\
$\mathrm{~S}_{2} \mathrm{O}_{3}{ }^{2-}$ & $5.84 \times 10^{-3}$ \\
$\mathrm{CO}_{3}{ }^{2-}$ & $7.94 \times 10^{-3}$ \\
$\mathrm{HCO}_{3}^{-}$ & $4.64 \times 10^{-4}$ \\
$\mathrm{NO}_{2}{ }^{-}$ & $1.35 \times 10^{-4}$ \\
$\mathrm{NO}_{3}{ }^{-}$ & $5.01 \times 10^{-4}$ \\
$\mathrm{SCN}^{-}$ & $2.92 \times 10^{-4}$ \\
$\mathrm{HPO}_{4}^{-}$ & $4.29 \times 10^{-3}$ \\
$\mathrm{CH}_{3} \mathrm{COO}^{-}$ & $1.16 \times 10^{-3}$ \\
\hline
\end{tabular}

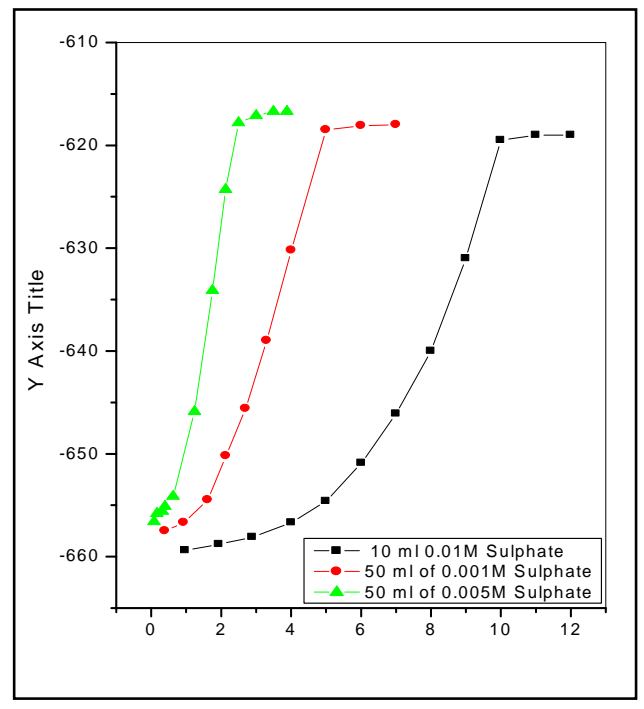

Fig. (6) Potentiometric titration curves for different concentration of sulfate solution, $1.0 \times 10^{-2} \mathrm{M}$ of $\mathrm{Ba}^{2+}$ (barium Nitrate).

Table (4) .Comparison of the selectivity coefficients of different electrodes .

\begin{tabular}{|c|c|c|c|c|c|}
\hline Anion & Ref 32 & Ref 33 & Ref 34 & Ref 35 & This Work \\
\hline $\mathrm{Br}$ & $3.2 \times 10^{-3}$ & $6.9 \times 10^{-3}$ & $7.9 \times 10^{-3}$ & $7.9 \times 10^{-4}$ & -- \\
$\mathrm{CO}_{3}{ }^{2-}$ & $6.3 \times 10^{-3}$ & $4.0 \times 10^{-3}$ & $3.3 \times 10^{-3}$ & $3.2 \times 10^{-4}$ & $7.94 \times 10^{-3}$ \\
$\mathrm{Cl}^{-}$ & $4.0 \times 10^{-3}$ & $4.9 \times 10^{-3}$ & $5.8 \times 10^{-3}$ & $5.0 \times 10^{-4}$ & $8.57 \times 10^{-4}$ \\
$\mathrm{CN}^{-}$ & $1.5 \times 10^{-2}$ & $4.0 \times 10^{-3}$ & $3.5 \times 10^{-4}$ & -- & - \\
$\mathrm{I}^{-}$ & $1.6 \times 10^{-2}$ & $8.0 \times 10^{-3}$ & $2.7 \times 10^{-4}$ & -- & $2.7 \times 10^{-3}$ \\
$\mathrm{NO}_{3}{ }^{-}$ & $6.2 \times 10^{-3}$ & $5.0 \times 10^{-3}$ & $3.4 \times 10^{-3}$ & $2.4 \times 10^{-4}$ & $5.01 \times 10^{-4}$ \\
$\mathrm{NO}_{2}{ }^{-}$ & $1.0 \times 10^{-2}$ & $9.9 \times 10^{-4}$ & $7.2 \times 10^{-2}$ & $5.3 \times 10^{-5}$ & $1.35 \times 10^{-4}$ \\
$\mathrm{SO}_{3}{ }^{2-}$ & $1.2 \times 10^{-3}$ & $7.9 \times 10^{-2}$ & $8.7 \times 10^{-3}$ & $4.9 \times 10^{-3}$ & $8.51 \times 10^{-3}$ \\
$\mathrm{SCN}^{-}$ & $7.9 \times 10^{-2}$ & $1.0 \times 10^{-4}$ & $3.4 \times 10^{4}$ & $7.8 \times 10^{-4}$ & $2.98 \times 10^{-4}$ \\
$\mathrm{ClO}_{4}^{-}$ & $3.1 \times 10^{-2}$ & $4.0 \times 10^{-3}$ & $3.6 \times 10^{-4}$ & $9.0 \times 10^{-4}$ & $1.99 \times 10^{-4}$ \\
$\mathrm{CH}_{3} \mathrm{COO}^{-}$ & $6.3 \times 10^{-3}$ & $3.1 \times 10^{-3}$ & -- & $1.6 \times 10^{-3}$ & $1.16 \times 10^{-3}$ \\
$\mathrm{HPO}_{4}{ }^{2-}$ & -- & -- & -- & $4.0 \times 10^{-5}$ & $4.29 \times 10^{-3}$ \\
\hline
\end{tabular}


Table (5) Determination of sulfate in some pharmaceutical formalastion using potintiomtric method \& turbidemetrey method .

\begin{tabular}{|c|c|c|c|c|}
\hline Sample \& sours & $\begin{array}{c}\text { Conc. mg/L } \\
\text { potentiometry }\end{array}$ & Recovery, \% & $\begin{array}{c}\text { Conc. mg/L } \\
\text { turbidemetrey }\end{array}$ & Recovery, $\%$ \\
\hline $\begin{array}{c}\text { Visceralgine, sedico } \\
\text { pharmaceutical . Co }\end{array}$ & $2.9 \pm 0.3 \mathrm{mg} / \mathrm{L}$ & $96.6 \%$ & $3.1 \pm 0.4 \mathrm{mg} / \mathrm{L}$ & $103.3 \%$ \\
\hline $\begin{array}{c}\text { Streptomycine, nileco } \\
\text { for farm \& chimical lnd }\end{array}$ & $\begin{array}{c}394.3 \pm 0.4 \\
\mathrm{mg} / \mathrm{L}\end{array}$ & $99.5 \%$ & $395 \pm 0.5 \mathrm{mg} / \mathrm{L}$ & $99.7 \%$ \\
\hline $\begin{array}{c}\text { Neomycine, Memphisco } \\
\text { for pharm chimical lnd }\end{array}$ & $94.9 \pm 0.2 \mathrm{mg} \backslash \mathrm{L}$ & $97.8 \%$ & $\begin{array}{c}95.5 \pm 0.3 \\
\mathrm{mg} / \mathrm{L}\end{array}$ & $98.4 \%$ \\
\hline
\end{tabular}

\section{References}

1. F. P. SCHMIDTCHEN AND M. BERGER, Chem. Rev. 97 (1997), pp. 1609-1646.

2. P. BÜHLMANN, E. PRETSCH AND E. BAKKER, Chem. Rev. 98 (1998), pp. $1593-$ 1687.

3. M. M. G. ANTONISSE AND D.N. REINHOUDT, Electroanalysis 11 (1999), pp. 1035 1048.

4. E. BAKKER, P. BÜHLMANN AND E. PRETSCH, Electroanalysis 11 (1999), pp. 915927

5. D. MIDGLEY, Ion-Sel. Electrode Rev. 8 (1986), pp. 3-54.

6. S. NISHIZAWA, P. BÜHLMANN, K.P. XIAO and Y. UMEZAWA, Anal. Chim. Acta 358 (1998), pp. 35-44

7. Z.-Q. LI, G.-D. LIU, L.-M. YUAN, G.-L. SHEN AND R.-Q. YU, Anal. Chim. Acta 382 (1999), pp. 165-170.

8. M. FIBBIOLI, M. BERGER, F.P. SCHMIDTCHEN AND E. PRETSCH, Anal. Chem. 72 (2000), pp. 156-160.

9. M. SHAMSIPUR, G. KHAYATION AND S. TANGESTANINEJAD, Electroanalysis 11 (1999), pp. 1340-1344.

10. M. R. GANJALI, L.NAJI, T.POURSABERI, M.TAGHIZADEH, H.pirelahi, Myosefi, A. yequnesh-fall , M. shmsi pur Talanta 58 (2002) 359

11. V.WUTHIER, H. V. PHAM, R. ZÜNI, D.WELTI, R.J.J. FANK, A. BEZEGH, D.AMMAN, E.PERISH, W. SIMON, Amal-Chem.56(1984) 535.

12. M. SHAMSIPUR, S. ROUHANI, A. MOHAJERI, M. R. GANJALI AND P. RASHIDIRANJBAR, Anal. Chim. Acta 418 (2000), pp. 197-203. 
13. S. AMEMIYA, P. BÜHLMANN, K. TOHDA AND Y. UMEZAWA, Anal. Chim. Acta 341 (1997), pp. 129-139.

14. R. S. HUTCHINS, P. BANSAL, P. MOLINA, H. ALAJARIN, A. VIDAL AND L.G. BACHAS, Anal. Chem. 69 (1997), pp. 1273-1275.

15. M. KATAOKA, R. NAGANAWA, K. ODASHIMA, Y. UMEZAWA, E. KIMURA AND T. KOIKE, Anal. Lett. 22 (1989), pp. 1089-1105.

16. R. NAGANAWA, H. RADECKA, M. KATAOKA, K. TOHDA, K. ODASHIMA, Y. UMEZAWA, E. KIMURA AND T. KOIKE, Electroanalysis 5 (1993), pp. 731-738.

17. C. M. CAREY AND W. B. RIGGAN, Anal. Chem. 66 (1994), pp. 3587-3591.

18. H. STEPHAN, K. GLOE, P. SCHIESSL AND F.P. SCHMIDTCHEN, Supramol. Chem. 5 (1995), pp. 273-280.

19. M. BERGER AND F. P. SCHMIDTCHEN, J. Am. Chem. Soc. 118 (1996), pp. 89478948.

20. E. BAKKER, P. BÜHLMANN AND E. PRETSCH, Chem. Rev. 97 (1997), pp. 30833132

21. S. K. NOROV, M. T. GULAMVA, A. F. ZHUKOV, G. H. NOROVA AND Y. G. MEMEDOVA, Zh. Anal. Khim. 43 (1988), pp. 986-991.

22. A. UGUR, B. MERCIEMK, M. ALZER, AND NSAHIN, TR metal chemistry 25 (2000) 421.

23. M. FAAL-RASTGAR, M. S. THESIS, Tehran University, Tehran, Iran, 27 (1995) 219.

24. M. FARNIA, A. KAKANEJADIFAR, S. KARIMI AND L.J. TODARO, J. Chem. \& Chem. Eng. 12 (1993), pp. 57-62.

25. S. KamatA, A. BHAle, Y. FUKUnAGA AND A. MURATA, Anal. Chem. 60 (1988), pp. 2464-2467.

26. IUPAC, IPURE and Applied chemistry, 74 (2002), 923.

27. S.NISHIZ AWA, P.BUHIMANN, K.P.XIAO, Y. UMEZAWA, Anel Chim. Acta 35 ( 1998) 358 .

28. Z. Q. LI, G.D.LIU, L. M.DUAN, G.L.SHEN, R.Q.YU, Anal.Chim. Acto 165 (1999) 382.

29. M. FIBBIOLI, M.BERGER, F.SCHMIDTCHEN, E. Pretsch Anal.Chem, 72 (2000) 156.

30. M. J. BERROCAL, A. CRUZ, I.H.A. BADER, L. G. BACHAS, Anal. Chem., 72 (2000) 5295.

31. M. MORIGI, E. SCAVETTA, M. BERRETTONI, M. GIORGETTI, D TONELLI, Anal. Chim. Acta, 439 (2001) 265. 
32. M. SHAMSIPUR, M. YOUSEFI, M. HOSSEINI, M. R.GANJALI, H. SHARGHI, H. Naemi, Anal. Chem., 73 (2001) 2869.

33. M. SHAMSIPUR, M. YOUSEEFI, M. HOSSEINI, M.R. GANJALI, T POURSABERI , AND M.FAAL-RASTGAR, Sens. Actuators, 82 (2002) 105 .

34. M. R.GANJAALI, L. NAJI, T. POURSABERI, M. TAGHIZADEH, HPIRELAHI, M. YOUSEFI, A. YEGANEH-FAAL, AND M. SHAMSIPUR, Talanta 58 (2002) 359.

35. M. GANJALI, M. POURJAVID, AND M. SHAMSIBUR, Analytical sciences 319 (2000) 203. 